\title{
ROCK USE TECHNOLOGY FOR IMPROVEMENT MICROBIOLOGICAL INDICATORS OF LEACHED CHERNOZEM
}

\author{
Valeriy Tskhovrebov, Valeriya Kukushkina, Vera Faizova, Dmitriy Kalugin, Anastasya Nikiforova \\ Stavropol State Agrarian University, Russia \\ tshovrebov@mail.ru
}

\begin{abstract}
Studies were conducted at the experimental station of the Stavropol State Agrarian University on leached chernozem, powerful, low-humus heavy loam on loess-like loam in 2017. The goal was to study the effect of the introduction of rocks rich in chemical composition (limestone-shell rock, apatite and phosphogypsum), both separately and jointly, on the microbial phase of the soil. The determination of the number of microorganisms was produced on dense nutrient medium by direct counting of colonies. It was found that the amount of ammonifiers under the control was 37 $\mathrm{ml} \mathrm{CFU} \mathrm{g}^{-1}$ (colony-forming units), increasing $1.3-1.5$ times with separate use and $2.5-3$ times with the joint use of rocks. Similar changes were observed with respect to the number of nitrifiers and aerobic nitrogen fixers of the type Azotobacter. The number of cellulose-depleting microorganisms in the remineralization variants reached 220,00230,00 CFU g ${ }^{-1}$ compared to $115,00 \mathrm{CFU} \mathrm{g}^{-1}$ under the control. With the introduction of separate rocks, there was a decrease in the occurrence of pathogens, while with a joint introduction they were not detected. The frequency of occurrence of toxin formers, such as Aspergillus and Penicillium, reached $100 \%$ at the control and decreased by $20-$ $40 \%$ at the experimental variants. It was revealed that the introduction of shell limestone, apatite and phosphogypsum had an effect on the increase in the number of soil microbiota of various physiological groups. Among the fungal microflora, the number of pathogens and toxin formers decreases and the number of pathogen antagonists increases. Key words: rocks, microorganisms, leached chernozem, pathogens, toxin formers, pathogen antagonists.
\end{abstract}

\section{Introduction}

Remineralization is a way to improve soil fertility by adding rocks that are rich in chemical composition. This method is widely used in the countries of northern Europe on poor soils of the podzolic type.

The object of research is leached chernozem, powerful low-humus heavy loam on loess loam. Chernozems are among the most fertile soils. They, however, do not have a single soil difference that does not require an increase in productive capacity (Tshovrebov et al., 2018; Esaulko et al., 2017).

We believe that leached chernozem needs remineralization. They are at the first stage of degradation (Korobskoi et al., 2012; Podkolzin et al., 2017; Vlasova et al., 2018). The analysis of the mineralogical composition indicates the outlined significant differences between the soil-forming rock and the soil. The alkaline medium of the parent rocks becomes slightly acidic and acidic in the soil. This is especially noticeable in agrocenoses (Russel, 1950; Tshovrebov et al., 2017). As a result of agricultural use, the rate of weathering of the mineral base increases, and the nutritional elements are alienated along with the harvest. This leads to inevitable poor nutrition and steadily declining soil fertility (Titova, Dabakhov, \& Dabakhova, 2002; Faizova, Tskhovrebov, \& Nikiforova, 2015). Fertilizers alone cannot solve this problem. It is necessary to constantly rejuvenate the mineral basis of soils with mountainous rocks rich in chemical composition.

Soil microflora causes soil formation processes. The number and activity of microorganisms in the soil undergo strong changes in the process of agricultural use of black soil. The microbial association must be considered as a mobile component of the soil that delivers trace elements to plants in a form that is accessible to plants.

\section{Materials and Methods}

The research was conducted at the experimental station of the Stavropol State Agrarian University in 2017. It is located in the Central part of the Stavropol upland. The climate is characterized by moderate moisture, the amount of precipitation $650-700 \mathrm{~mm}$ and the sum of active temperatures of $2800-3000$ ${ }^{\circ} \mathrm{C}$. The relief is flat, parent rocks are loess-like loam. Leached chernozem differs from other topsoil in that the carbonates are washed outside of the soil profile. Many of the nutrition elements released from minerals are removed with them. The main disadvantage of the investigated soils is low or close to low content of mobile phosphorus $(15-17 \mathrm{mg}$ $\mathrm{kg}^{-1}$ ), potassium $(180-210 \mathrm{mg} \mathrm{kg}$ ), sulfur (3.0 to $\left.4.0 \mathrm{mg} \mathrm{kg}^{-1}\right)$, and micronutrient deficiencies such as manganese, molybdenum, cobalt, zinc and copper. In addition, in the absence of free calcium, the soils possess a high degree of fusion, structurelessness, and in the dry period are covered by deep and wide vertical cracks. We can assume that this soil type is in the first stage of degradation. Therefore, the aim of the research is to study the impact of making the rich chemical composition of rocks (limestone, apatite and phosphogypsum) separately and jointly on the microflora of the soil.

Such rocks as apatite, shell limestone and phosphogypsum were introduced as waste in the production ofmineral phosphate fertilizers. We made both separate and joint introduction of them according to the 
Table 1

Gross content of nutrients in rocks\%

\begin{tabular}{|l|c|c|c|c|c|c|c|c|}
\hline Rock & $\mathrm{P}_{2} \mathrm{O}_{5}$ & $\mathrm{~S}$ & $\mathrm{~B}$ & $\mathrm{Mn}$ & $\mathrm{Cu}$ & $\mathrm{Zn}$ & $\mathrm{Co}$ & $\mathrm{Mo}$ \\
\hline Phosphogypsum & 3.4 & 20.2 & 0.1 & 1.0 & 0.01 & 0.05 & 0.03 & 0.05 \\
\hline Shell limestone rock & 0.24 & - & 0.2 & 1.5 & 0.5 & 1.5 & 0.2 & 0.13 \\
\hline Apatite & 41.0 & - & 0.15 & 2.3 & 0.4 & 1.3 & 0.09 & 0.1 \\
\hline
\end{tabular}

following scheme: 1) Control; 2) Shell limestone rock $6 \mathrm{t} \mathrm{ha}^{-1}$; 3) Shell limestone rock - $12 \mathrm{t} \mathrm{ha}^{-1}$; 4) Apatite $1.5 \mathrm{t} \mathrm{ha}^{-1}$; 5) Apatite - $3.0 \mathrm{t} \mathrm{ha}^{-1}$; 6) Phosphogypsum $12 \mathrm{t} \mathrm{ha}^{-1}$; 7) Shell limestone rock $-6 \mathrm{t} \mathrm{ha}^{-1}+$ apatite $1.5 \mathrm{t} \mathrm{ha}^{-1}$; 8) Shell limestone rock $-12 \mathrm{tha}^{-1}+$ apatite $3.0 \mathrm{t} \mathrm{ha}^{-1}$; 9) Shell limestone $-6 \mathrm{t} \mathrm{ha}^{-1}+$ apatite $1.5 \mathrm{t} \mathrm{ha}^{-1}+$ gypsum $-12 \mathrm{tha}^{-1}$;0) Shell limestone rock $12 \mathrm{t} \mathrm{ha}^{-1}+$ apatite $-3.0 \mathrm{tha}^{-1}+$ gypsum $-12 \mathrm{tha}^{-1}$.

The choice of rocks is due to the content of a large number of micro-and macro-elements (Table 1).

Shell limestone is a rich sedimentary rock of biogenic origin which contains $\mathrm{Ca}-36-37 \%$; $\mathrm{Mg}-0.48 \%$, as well as macro and micronutrients (Table 1). This type was delivered from the quarry of Mount Nedremanny, located at a distance of $30 \mathrm{~km}$ from the experimental site.

Apatite is mined on the Kola Peninsula and transported to the city of Lermontov for the production of phosphate fertilizers. It also contains fairly large gross reserves of macro and micronutrients.

Phosphogypsum is obtained from the production of phosphate fertilizers by irrigation with sulfuric acid. The resulting phosphoric acid is used for the production of fertilizers and gypsum is a by-product. Its reserves in the Stavropol region are estimated at millions of tons. It is also a relatively rich improver in chemical composition.

Shell limestone is needed to increase the content of free calcium and trace elements; apatite is necessary to increase the content of phosphorus, calcium and trace elements. Phosphogypsum is used to eliminate the deficiency of sulfur and calcium in the soil.

The introduction of improvers was made fractional. Half of the dose was scattered directly on the stubble, BDT -7 was dispelled to the depth of $10-12 \mathrm{~cm}$, followed by plowing to the depth of $20-25 \mathrm{~cm}$. Then the second half was added to the ameliorant and BDT 7 was harrowed, thus achieving complete mixing of the soil with ameliorants. The sown crop was maize for grain (Veralia hybrid).

The determination of microorganism number was made on dense selective nutrient medium: on meat-peptone agar - the number of ammonifiers; on ammonium starch agar - the number of microorganisms that assimilate the mineral forms of nitrogen; on the medium Getchenson - the number of cellulosedepleting microorganisms; on the medium of Chapekdoksa - the number of micromycetes. Incubation was carried out in thermostats at a temperature of $+28^{\circ} \mathrm{C}$. Mathematical processing of the data was carried out according to the Dospehov method.

\section{Results and Discussion}

We have conducted the studies of soil microflora state in the flowering phase of maize. It was found that the number of ammonificators in the flowering phase of maize under control was 36.8 million CFU g-1 (Table 2). The use of shell limestone in doses of 6 and $12 \mathrm{t}$ $\mathrm{ha}^{-1}$ increased the number of these microorganisms by 1.5 and 2.2 times, respectively. The introduction of apatite in doses of 1.5 and $3 \mathrm{tha}^{-1}$ and phosphogypsum did not significantly affect the amount of ammonifiers. The joint introduction of rocks had a more significant effect on the number of this group of microorganisms with an increase of 1.6 to 2.6 times. The greatest difference was noted in the joint introduction of rocks in maximum doses.

Studying microorganism number that convert the mineral forms of nitrogen, the dependence inherent to ammonificators is revealed. There is a close metabiotic relationship between soil microorganisms involved in ammonification and nitrification processes. As a result of this relationship, in vivo excretions of ammonifiers serve as food for microorganisms that convert mineral forms of nitrogen. For this reason, changes in the number of nitrifiers are similar to changes in the number of microorganisms that convert organic forms of nitrogen.

The number of aerobic nitrogen fixers at the control was $26,1 \mathrm{CFU} \mathrm{g}^{-1}$ with the addition of shell lime in doses of 6 and 12 tha $^{-1}$ increased 2.6 and 2.8 times, respectively. The introduction of apatite in doses of 1.5 and $3 \mathrm{t} \mathrm{ha}^{-1}$ and phosphogypsum provided not so significant increase in the number of this group of microorganisms, only $1.3-1.4$ times. With the joint introduction of rocks, the number of microorganisms of the type Azotobacter increased $2.1-2.4$ times. Such dependence, in our opinion, is explained by more favorable conditions for the nutrition of the plants themselves and an increase in the content of trace elements, among which molybdenum plays the most decisive role. It is part of the enzyme nitrogenase and contributes to the activation of nitrogen fixation processes.

In all variants of the experiment, the number of cellulose-depleting microorganisms was higher than under the control. The smallest difference was found 
The number of different physiological groups of microorganisms in the soil in the flowering phase of maize depending on the introduction of rocks

\begin{tabular}{|c|c|c|c|c|c|}
\hline Test form & $\begin{array}{c}\text { Ammonifiers } \\
(\mathrm{mln} . \mathrm{CFU} \\
\left.\mathrm{g}^{-1}\right)\end{array}$ & $\begin{array}{l}\text { Nitrifiers } \\
(\mathrm{mln} . \\
\left.\text { CFU g }{ }^{-1}\right)\end{array}$ & $\begin{array}{c}\text { Aerobic } \\
\text { nitrogen } \\
\text { fixers (CFU } \\
\left.\mathrm{g}^{-1}\right)\end{array}$ & $\begin{array}{l}\text { Cellulose- } \\
\text { depleting } \\
\left.(\mathrm{CFU} \mathrm{g})^{-1}\right)\end{array}$ & $\begin{array}{l}\text { Fungi } \\
\left(\mathrm{CFU} \mathrm{g}^{-1}\right)\end{array}$ \\
\hline 1. Control & 36.8 & 31.2 & 26,1 & 112,7 & 156,5 \\
\hline 2. Shell limestone $6 \mathrm{t} \mathrm{ha}^{-1}$ & 55.2 & 49.6 & 67,0 & 129,1 & 197,6 \\
\hline 3. Shell limestone $12 \mathrm{t} \mathrm{ha}^{-1}$ & 82.5 & 71.3 & 72,3 & 145,8 & 275,1 \\
\hline 4. Apatite $1.5 \mathrm{t} \mathrm{ha}^{-1}$ & 31.2 & 28.4 & 33,7 & 154,8 & 197,4 \\
\hline 5. Apatite $3 \mathrm{t} \mathrm{ha}^{-1}$ & 37.5 & 32.1 & 32,9 & 132,0 & 242,0 \\
\hline 6. Phosphogypsum $12 \mathrm{tha}^{-1}$ & 40.2 & 35.7 & 35,7 & 163,5 & 273,5 \\
\hline 7. Shell lime $6 \mathrm{tha}^{-1}+$ apatite $1.5 \mathrm{t} \mathrm{ha}^{-1}$ & 59.9 & 51.0 & 46,2 & 157,8 & 297,5 \\
\hline 8. Shell lime $12 \mathrm{t} \mathrm{ha}^{-1}+$ apatite $3 \mathrm{t} \mathrm{ha}^{-1}$ & 84.2 & 72.4 & 69,0 & 230,6 & 264,2 \\
\hline $\begin{array}{l}\text { 9. Shell limestone } 6 \mathrm{t} \mathrm{ha}^{-1}+\text { apatite } 1.5 \mathrm{tha}^{-1}+ \\
\text { phosphogypsum } 12 \mathrm{t} \mathrm{ha}^{-1}\end{array}$ & 61.2 & 54.3 & 57,2 & 218,7 & 222,0 \\
\hline $\begin{array}{l}\text { 10. Shell limestone } 12 \mathrm{tha}^{-1}+\text { apatite } 3 \mathrm{tha}^{-1}+ \\
\text { phosphogypsum } 12 \mathrm{t} \mathrm{ha}^{-1}\end{array}$ & 94.3 & 85.1 & 69,7 & 261,6 & 371,6 \\
\hline $\mathrm{HCP}_{05} \mathrm{CFU} / \mathrm{g}$ & 8.3 & 9.4 & 7,1 & 15,4 & 21,1 \\
\hline
\end{tabular}

Frequency of micromycete occurrence in the soil under maize depending on the

Table 3 after effect of rocks, \%

\begin{tabular}{|c|c|c|c|c|c|c|c|c|c|c|c|c|c|c|c|}
\hline \multirow[b]{2}{*}{ Experimental variant } & \multicolumn{6}{|c|}{ Pathogens Toxiners } & \multicolumn{2}{|c|}{$\begin{array}{c}\text { Other } \\
\text { saprophytes }\end{array}$} & \multicolumn{3}{|c|}{$\begin{array}{c}\text { Other } \\
\text { saprophytes }\end{array}$} & \multicolumn{3}{|c|}{$\begin{array}{l}\text { Pathogen } \\
\text { antagonists }\end{array}$} & \multirow[b]{2}{*}{$\begin{array}{l}\text { Shannon } \\
\text { diversity } \\
\text { index }\end{array}$} \\
\hline & 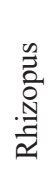 & 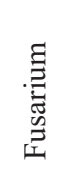 & $\underbrace{\infty}_{0}$ & 吾 & 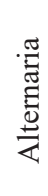 & 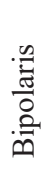 & 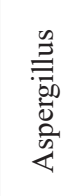 & 当 & 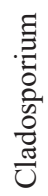 & $\frac{\pi}{\overparen{\pi}}$ & $\stackrel{0}{0}^{\stackrel{0}{Z}}$ & $\begin{array}{l}\frac{\pi}{\overline{0}} \\
\stackrel{0}{0} \\
\stackrel{0}{0}\end{array}$ & 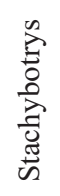 & 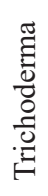 & \\
\hline 1. Control & 60 & 100 & 20 & 40 & 40 & 40 & 100 & 100 & 40 & 60 & 20 & 60 & 60 & - & 0.94 \\
\hline 2. Shell limestone $6 \mathrm{t} \mathrm{ha}^{-1}$ & 40 & 60 & - & 20 & 40 & 20 & 60 & 80 & 20 & 60 & 20 & 80 & 20 & - & 0.99 \\
\hline 3. Shell limestone $12 \mathrm{t} \mathrm{ha}^{-1}$ & 20 & 60 & - & 20 & 40 & 20 & 60 & 60 & 20 & 80 & - & 80 & 20 & - & 1.09 \\
\hline 4. Apatite $1.5 \mathrm{t} \mathrm{ha}^{-1}$ & - & 80 & 20 & - & 60 & 40 & 80 & 80 & - & 60 & - & 60 & 40 & - & 1.42 \\
\hline 5. Apatite $3 \mathrm{t} \mathrm{ha}^{-1}$ & - & 80 & - & - & 60 & 20 & 60 & 80 & 20 & 60 & 40 & 60 & 40 & - & 1.48 \\
\hline 6. Phosphogypsum $12 \mathrm{t} \mathrm{ha}^{-1}$ & 20 & 80 & 20 & - & 60 & 20 & 80 & 80 & - & 60 & 40 & 60 & 20 & - & 1.50 \\
\hline $\begin{array}{l}\text { 7. Shell limestone } 6 \mathrm{t} \mathrm{ha}^{-1}+ \\
\text { Apatite } 1.5 \mathrm{t} \mathrm{ha}^{-1}\end{array}$ & - & 60 & - & - & 60 & 20 & 60 & 60 & - & 80 & - & 80 & 20 & 20 & 1.77 \\
\hline $\begin{array}{l}\text { 8. Shell limestone } 12 \mathrm{tha}^{-1}+ \\
\text { apatite } 3 \mathrm{tha}^{-1}\end{array}$ & - & 40 & - & - & 40 & - & 40 & 60 & - & 80 & - & 80 & 20 & 20 & 1.83 \\
\hline $\begin{array}{l}\text { 9. Shell limestone } 6 \mathrm{t} \mathrm{ha}^{-1}+ \\
\text { Phosphogypsum } 12 \mathrm{t} \mathrm{ha}^{-1}\end{array}$ & - & 40 & - & - & 20 & - & 40 & 60 & - & 100 & - & 80 & 20 & 20 & 2.06 \\
\hline $\begin{array}{l}\text { 10. Shell limestone } 12 \mathrm{tha}^{-1}+ \\
\text { Apatite } 3 \mathrm{tha}^{-1}+ \\
\text { Phosphogypsum } 12 \mathrm{t} \mathrm{ha}^{-1}\end{array}$ & - & 40 & - & - & 20 & - & 40 & 60 & - & 100 & - & 80 & 20 & 20 & 2.11 \\
\hline
\end{tabular}

when making shell limestone at doses of 6 and $12 \mathrm{tha}^{-1}$ (1.1 and 1.3 times, respectively) and apatite at doses of 1.5 and $3 \mathrm{t} \mathrm{ha}^{-1}$ (1.4 and 1.2 times, respectively). The introduction of phosphogypsum caused an increase in the number of microorganisms studied by 1.5 times and amounted to $163,5 \mathrm{CFU} \mathrm{g}^{-1}$. The largest number of cellulolytics $\left(261,6 \mathrm{CFU} \mathrm{g}^{-1}\right)$ was noted with the joint introduction of rocks in maximum doses.

The number of micromycetes under the control was $156,5 \mathrm{CFU} \mathrm{g}^{-1}$ of soil. With the addition of shell 
limestone in doses of 6 and 12 tons per hectare, the studied value increased by 1.4 and 1.8 times, respectively. On variants of joint introduction of rocks, the studied indicator tended to increase. At the maximum doses of rocks, the number of micromycetes increased 2.4 times and amounted to $371,6 \mathrm{CFU} \mathrm{g}^{-1}$.

To determine the phytosanitary condition of the soil, we studied the generic composition of fungi, their frequency of occurrence and divided them into 4 groups: pathogens, toxin-formers, antagonists of pathogens, and other saprophytes.

The highest occurrence of such pathogens as Rhizopus (60\%), Fusarium (100\%), Verticillium (40\%), Alternaria (40\%), Bipolaris (40\%) was found under the control. Microorganisms of the type Botrytis had the lowest occurrence (Table 3). With the introduction of rocks a decrease in the occurrence of pathogens was found and with the joint introduction of ameliorants, fungi of the type Rhizopus, Verticillium and Bipolaris were not detected. The frequency of occurrence of toxin formers, such as Aspergillus and Penicillium, reached $100 \%$ under control and decreased by $20-40 \%$, especially with the joint introduction of rocks. The frequency of occurrence of pathogen antagonists increased with the options for the application of mountain weather, while the number of other saprophytes decreased. It should be noted that antagonist fungi of various pathogens of the type Trichoderma were not found under the control and variants with separate use of rocks, and were found on variants with their joint introduction.

The frequency of occurrence of micromycetes on the Shannon index is considered to be poor under control (0.94) and rich in the joint introduction of rocks (2.11). A richer community indicates a better medium sustainability of the soil system when introducing most of the rocks.

\section{Conclusions}

Thus, as a result of the research, it was found that the number of microorganisms has changed in all variants of the experiment compared to the control. The introduction of shell limestone, apatite and phosphogypsum has a certain effect on the increase in the number of soil microbiota of various physiological groups. Among the fungal microflora, as a result of remineralization of leached chernozem, the number of pathogens and toxin-formers decreases and the number of antagonists of pathogens increases. The abundance of micromycetes according to the Shannon index is considered poor under control (0.94) and rich when rocks are introduced together $(2.03-2.11)$.

\section{References}

1. Esaulko, A., Ozheredova, A., Sigida, M., Voskoboinikov, A., \& Podkolzin, O. (2017). Introduction of calculated doses of mineral fertilizers to achieve maximum productivity of winter wheat varieties on chernozem leached Stavropol upland. Research Journal of Pharmaceutical, Biological and Chemical Sciences. 8(6), 778-781.

2. Faizova, V., Tskhovrebov, V., \& Nikiforova, A. (2015). Formation of soil fungus groups into black soil Central Ciscaucasus by agrarian using. Harvard Journal of Fundamental and Applied Studies. 1(8), 729735 .

3. Korobskoi, N., Slusarev, V., Barakina, E., \& Shvets, A. (2012). Биологическая активность чернозема выщелоченного Западного Предкавказья под озимой пшеницей (Biological activity of leached chernozem of Western Ciscaucasia under winter wheat). Politematich. network electronic scientific. Journal KubGAU. 2, 232. (in Russian)

4. Podkolzin, O., Sokolova, I., Osipov, A., \& Slusarev, V. (2017). Monitoring soil fertility of the lands of the Krasnodar Territory. Proceedings of the Kuban State Agrarian University. 68, 117-124.

5. Russel, E.L. (1950). Soil conditions and plant growth. Soil Sci. 9, (pp. 231-244). Academic Press.

6. Titova, V., Dabakhov, M., \& Dabakhova, E. (2002). Агроэкосистемы: проблемы функционирования и поддержания устойчивости (Agroecosystems: problems of functioning and maintaining sustainability). 205. N. Novgorod: NSHA. (in Russian)

7. Tshovrebov, V., Faizova, V., Kalugin, D., Nikiforova, A., \& Lysenko, V. (2018). Influence of biological products and their metabolites on the number and seasonal dynamics of micromycetes in ordinary chernozems of the Central Ciscaucasia. Research Journal of Pharmaceutical, Biological and Chemical Sciences. RJPBCS 9(6), 18-41.

8. Tskhovrebov, V., Faizova, V., Nikiforova, A., Novikov, A., \& Marin, A. (2017). Soil fertility problems in Central Ciscaucasia. Research journal of pharmaceutical biological and chemical sciences. 8(6), 574-580.

9. Vlasova, O., Perederiev, V., Volters, I, Drepa, E., \& Danilets, E. (2018). Previous crop - as an element of organic farming in the cultivation of winter wheat in the Central Ciscaucasia. Research Journal of Pharmaceutical, Biological and Chemical Sciences. 9(6), 1272-1276. 